\title{
PERAKITAN STRAIN IKAN LELE Clarias gariepinus (Burchell, 1822) TUMBUH CEPAT MELALUI SELEKSI INDIVIDU: PEMBENTUKAN POPULASI GENERASI PERTAMA
}

\author{
Bambang Iswanto, Imron, Rommy Suprapto, dan Huria Marnis \\ Balai Penelitian Pemuliaan Ikan \\ Jl. Raya 2 Sukamandi, Subang 41263 \\ E-mail: bambang.is031@kkp.go.id
}

(Naskah diterima: 23 Agustus 2013; Revisi final: 14 Oktober 2014; Disetujui publikasi: 10 November 2014)

\begin{abstract}
ABSTRAK
Ikan lele Afrika (Clarias gariepinus) di Indonesia telah mengalami penurunan genetis, ditandai dengan rendahnya keragaan pertumbuhannya, sehingga diperlukan upaya pemuliaan. Pemuliaan dalam rangka merakit strain ikan lele Afrika tumbuh cepat dapat dilakukan melalui program seleksi. Pemuliaan ikan lele melalui program seleksi di Balai Penelitian Pemuliaan Ikan Sukamandi telah diawali pada tahun 2010 melalui koleksi, karakterisasi, dan evaluasi strain-strain yang potensial, dilanjutkan dengan pembentukan populasi dasar sintetis pada tahun 2011. Selanjutnya, pada tahun 2012 dilanjutkan dengan pembentukan populasi generasi pertama melalui pemijahan 50 pasang ikan lele populasi dasar sintetis. Keragaan pertumbuhan populasi generasi pertama dievaluasi dan dibandingkan dengan populasi kontrol (merepresentasikan keragaan populasi dasar sintetis) untuk mengetahui besarnya respons seleksi. Hasil dari evaluasi menunjukkan bahwa respons seleksinya sebesar $20,59 \%$ pada karakter bobot dan setara dengan $6,12 \%$ pada karakter panjang total. Hasil tersebut mengindikasikan bahwa populasi generasi pertama yang keragaan pertumbuhannya lebih baik daripada populasi dasar sintetis potensial untuk digunakan sebagai pembentuk populasi generasi berikutnya dalam rangka merakit strain ikan lele tumbuh cepat melalui program seleksi.
\end{abstract}

KATA KUNCl: seleksi individu, respons seleksi, pertumbuhan, generasi pertama, ikan lele Afrika, Clarias gariepinus

ABSTRACT: Establishment of a rapid growth strain of African catfish Clarias gariepinus (Burchell, 1822) by means of individual selection: Production the first generation population. By: Bambang Iswanto, Imron, Rommy Suprapto, and Huria Marnis

Introduced African catfish Clarias gariepinus in Indonesia has experienced increasing genetic deterioration, led to poor growth performance. Therefore, genetic improvement program is needed. Genetic improvement in the establishment of a rapid growth strain of African catfish might be achieved through selective breeding program. The selective breeding program at the Research Institute for Fish Breeding Sukamandi has been started since 2010 through collection, characterization, and evaluation of the potential strains, followed by the building of the synthetic base population in 2011 . Then, in 2012 it was continued by building the first generation through mating of 50 pairs of selected individuals from the synthetic base population. Growth performances of the first generation population was evaluated, and compared 
to the control population (represented the synthetic base population) in order to estimate the selection response. Results of the evaluation showed that selection response was $20.59 \%$ for body weight, and corresponded to $6.12 \%$ for the total length. Those results suggested that the first generation population, for which its growth performance was better than the synthetic base population, was potential as the foundation of the next generation in the establishment of a rapid growth strain of African catfish by means of selective breeding program.

\section{KEYWORDS: individual selection, selection response, growth, first generation,} African catfish, Clarias gariepinus

\section{PENDAHULUAN}

Ikan lele merupakan salah satu komoditas perikanan yang diprioritaskan pengembangan budidayanya oleh Kementerian Kelautan dan Perikanan (KKP, 2010). Ikan lele Afrika Clarias gariepinus merupakan spesies ikan lele yang kuat, relatif tahan terhadap patogen, laju pertumbuhannya tinggi, dan dapat dipijahkan sepanjang tahun, sehingga sangat potensial sebagai komoditas perikanan budidaya dan telah diintroduksi, serta berkembang di banyak negara (Na-Nakorn \& Brummet, 2009), termasuk Indonesia (Hardjamulia et al., 2001). Introduksi ikan lele Afrika ke Indonesia telah beberapa kali dilakukan. Namun demikian, dikarenakan kurang tepatnya manajemen induk, maka mutu genetisnya telah menurun, sehingga diperlukan upaya pemuliaan.

Upaya pemuliaan dalam rangka merakit strain ikan lele Afrika unggul dapat dilakukan melalui program seleksi, dan program seleksi yang paling penting dilakukan adalah seleksi berdasarkan karakter laju pertumbuhan pada saat ukuran konsumsi (Brummet, 2008; Nguyen \& Ponzoni, 2008). Perbedaan (variasi) ukuran dan laju pertumbuhan yang tinggi banyak dilaporkan pada benih ikan lele Afrika (Rezk, 2008). Perbedaan pertumbuhan tersebut bersifat konsisten dan merupakan akibat dari adanya perbedaan tingkah laku (kebiasaan) makan dan efisiensi pemanfaatan pakan yang bersifat diwariskan (Martins et al., 2005a; 2005b; 2005c). Dengan demikian, program seleksi pada karakter laju pertumbuhan ikan lele Afrika memungkinkan untuk dilakukan (Martins et al., 2005c).

Penelitian peningkatan keragaan pertumbuhan ikan lele Afrika melalui seleksi individu dan famili pernah dilakukan di Belgia dengan bantuan marka DNA mikrosatelit (Volkcaert \& Hellemans, 1999); namun demikian, peningkatan keragaan pertumbuhan yang dihasilkan relatif rendah, diduga akibat rendahnya ke- ragaman genetis. Upaya perbaikan genetis ikan lele Afrika melalui program seleksi juga dilakukan di Mesir sejak tahun 2005 (Rezk, 2008), tetapi hasil-hasilnya (respons seleksi atau heritabilitas) belum dilaporkan. Di Indonesia, upaya peningkatan keragaan pertumbuhan ikan lele Afrika melalui program seleksi dilakukan oleh Balai Penelitian Pemuliaan Ikan, Sukamandi. Tahap koleksi, karakterisasi, dan evaluasi sumberdaya genetis telah dilakukan pada tahun 2010 (Imron et al., 201 1); dilanjutkan dengan pembentukan populasi dasar sintetis pada tahun 2011 (Iswanto et al., 2012). Selanjutnya, pada tahun 2012 dilanjutkan dengan uji respons seleksi dan pembentukan populasi generasi pertama. Penelitian uji respons seleksi dan pembentukan populasi generasi pertama tersebut bertujuan untuk membentuk populasi generasi pertama ikan lele tumbuh cepat dan mengetahui besarnya respons seleksi sebagai bagian dari rangkaian kegiatan penelitian perakitan strain ikan lele tumbuh cepat.

\section{BAHAN DAN METODE}

Prosedur pembentukan populasi generasi pertama, penghitungan respons seleksi dan heritabilitas, serta teknik seleksi populasi generasi pertama pada penelitian ini dilakukan dengan berpedoman pada prinsip-prinsip manajemen induk dan program seleksi yang diberikan (direview) oleh Gjedrem (2005), Gjedrem \& Baranski (2009), serta Protokol Pemuliaan Ikan Lele dan Perbanyakan Induk Ikan Lele (Pusat Lele Nasional, 2010).

Populasi generasi pertama dibentuk melalui pemijahan 50 pasang ikan lele populasi dasar sintetis yang telah dibentuk pada tahun 2011 dan terdiri atas dua populasi (Iswanto et al., 2012); masing-masing populasi sebanyak 25 pasang. Jantan populasi dasar sintetis pertama dipijahkan dengan betina populasi dasar sintetis kedua dan sebaliknya. Hal tersebut dilakukan untuk mengurangi tingkat inbreed- 
ing. Pada saat yang bersamaan juga dipijahkan lima pasang ikan lele populasi kontrol sebagai pembanding untuk mengetahui besarnya capaian peningkatan genetis (dinyatakan sebagai respons seleksi) dari kegiatan seleksi karakter laju pertumbuhan yang dilakukan.

Proses pemijahan dilakukan secara buatan dengan stimulasi secara hormonal menggunakan ovaprim (Syndell Laboratories Inc., Kanada) sebanyak $0,2 \mathrm{~mL} / \mathrm{kg}$ induk betina dan $0,1 \mathrm{~mL} / \mathrm{kg}$ induk jantan. Pengambilan sperma dengan cara gonadektomi parsial dilakukan enam jam setelah penyuntikan hormon. Sperma dari seluruh individu induk jantan pada masing-masing populasi digabung (pooled) dan diencerkan menggunakan larutan $\mathrm{NaCl}$ fisiologis 0,9\% (PT Widatra Bhakti, Pandaan, Pasuruan) dengan perbandingan volume 1:50, kemudian disimpan dalam lemari es (suhu $4^{\circ} \mathrm{C}$ ) hingga digunakan dalam proses fertilisasi. Pengambilan telur induk betina melalui pengurutan (stripping) mulai dilakukan tujuh jam setelah penyuntikan hormon. Sebanyak $100 \mathrm{~g}$ telur masing-masing induk betina difertilisasi dengan sperma gabungan dan ditetaskan dalam dasar hapa berukuran $1 \mathrm{~m} \times 1 \mathrm{~m}$ (kepadatan telur sekitar $75.000 \mathrm{butir} / \mathrm{m}^{2}$ ) yang ditempatkan dalam bak beton di dalam hatcheri dengan air yang tersirkulasi.

Larva hasil penetasan dipindahkan ke dalam akuarium ketika berumur dua hari dan dipelihara hingga umur 25 hari. Padat tebar yang digunakan sebesar 30 ekor larva/L. Pakan yang diberikan pada saat larva berumur 3-5 hari berupa nauplii Artemia sp. (Supreme Plus, Golden West, Amerika Serikat), selanjutnya secara bertahap diganti dengan cacing sutera (Tubifex sp.) dan pakan komersial bentuk halus dengan kadar protein 40\% (BINTANG 581 dan 582, PT Centralproteina Prima, Mojokerto). Pakan diberikan pada pagi, siang, dan sore hari secara ad libitum. Pertumbuhan diamati melalui pengukuran panjang total dan bobot pada awal dan akhir periode pemeliharaan sebanyak $2 \%$ dari jumlah awal penebaran.

Seluruh benih hasil pemeliharaan dalam akuarium selanjutnya dipindahkan dan dipelihara dalam bak-bak beton yang telah kaya dengan pakan alami sebagai kolam pendederan selama satu bulan dengan padat tebar 300 ekor $/ \mathrm{m}^{2}$. Pakan yang diberikan selama tahap pendederan berupa pakan komersial berbentuk halus dengan kadar protein $40 \%$
(BINTANG 581 dan 582, PT Centralproteina Prima, Mojokerto), dilanjutkan dengan pakan komersial berbentuk pelet apung berukuran kecil dengan kadar protein 30\% (HI-PRO-VITE 781-1, PT Centralproteina Prima, Mojokerto), diberikan pada pagi, siang, dan sore hari secara ad libitum. Pertumbuhan diamati melalui pengukuran panjang total dan bobot pada awal dan akhir periode pemeliharaan sebanyak $2 \%$ dari jumlah awal penebaran.

Seluruh benih hasil pendederan selanjutnya dipindahkan dan dipelihara dalam kolam tanah sebagai kolam pembesaran selama dua bulan dengan padat tebar $150 \mathrm{ekor} / \mathrm{m}^{2}$. Pakan yang diberikan selama tahap pembesaran berupa pakan komersial dengan kadar protein 30\% (HI-PRO-VITE 781-2 dan 781, PT Centralpangan Pertiwi, Karawang), diberikan pada pagi dan sore hari secara ad libitum. Pertumbuhan diamati melalui pengukuran panjang total dan bobot setiap 20 hari sekali, sebanyak $2 \%$ dari jumlah awal penebaran. Pada akhir masa pembesaran dilakukan pengukuran panjang total dan bobot sebanyak $5 \%$ dari masing-masing populasi generasi pertama dan populasi kontrol, sehingga distribusi ukuran masing-masing populasi diketahui. Dengan demikian, besarnya heritabilitas dan respons seleksi dapat diketahui. Respon seleksi $(R)$ dihitung sebagai $R=$ (rata-rata keragaan populasi G1) - (rata-rata keragaan populasi kontrol), sedangkan heritabilitas nyata $\left(h^{2}\right)$ dihitung dengan rumus $h^{2}=($ respons seleksi pada populasi G 1$):($ diferensial seleksi pada pembentukan populasi dasar sintetis). Berdasarkan distribusi tersebut, populasi kontrol dibentuk melalui pemilihan individu-individu yang berukuran rata-rata. Selanjutnya, batas minimum ukuran individu-individu populasi generasi pertama yang ditetapkan lolos seleksi pada masingmasing populasi betina dan jantan dapat diketahui (yakni 5\% individu-individu berukuran terbesar), sehingga populasi generasi pertama hasil seleksi dapat dibentuk. Selain itu, besarnya diferensial seleksi $(S)$ juga dapat dihitung, yakni $S=$ (ukuran rata-rata populasi G1 terseleksi) - (ukuran rata-rata keseluruhan populasi G1).

Data yang diperoleh dianalisis secara statistik deskriptif dan inferensia. Data disajikan dalam bentuk nilai kisaran dan nilai rata-rata yang dilengkapi dengan simpangan baku. Selain itu, data juga disajikan dalam bentuk tabel dan grafik. 


\section{HASIL DAN BAHASAN}

\section{Keragaan Pertumbuhan dan Respons Seleksi Populasi Generasi Pertama}

Larva-larva hasil penetasan dari telur masing-masing induk betina yang difertilisasi dengan sperma gabungan dari keseluruhan induk jantan tetap dipelihara secara terpisah dalam akuarium-akuarium di dalam hatcheri, mengikuti prosedur yang dilakukan oleh Volckaert \& Hellemans (1999). Hal tersebut dimaksudkan untuk meminimumkan dampak negatif dari pengaruh maternal (maternal ef$f e c t$ ), dengan memberikan kondisi pemeliharaan yang optimum dan meminimumkan kompetisi, serta predasi (kanibalisme) antar progeni yang berbeda induk agar sintasannya terjamin seluruhnya. Tahap pembenihan selama 25 hari tersebut menghasilkan sintasan sebesar $71,86 \pm 9,73 \%(64,64 \%-79,91 \%)$; sedangkan pada tahap pendederan selama 30 hari menghasilkan sintasan sebesar $54,27 \pm 10,43 \%$ $(42,36 \%-63,82 \%)$ dan pada tahap pembesaran selama 60 hari menghasilkan sintasan sebesar $65,27 \%$.

Ukuran panjang total larva hasil penetasan telur induk-induk populasi dasar sintetis terseleksi $(2,66 \pm 0,02 \mathrm{~mm})$ dan populasi kontrol $(2,65 \pm 0,04 \mathrm{~mm})$, tidak berbeda nyata $(P>$ $0,05)$. Bobot larva yang baru menetas tidak diukur, karena pengukuran bobot larva yang baru menetas sulit dilakukan secara akurat. Namun demikian, oleh karena ukuran panjang totalnya tidak berbeda nyata, maka diduga dan dapat diasumsikan bahwa ukuran bobotnya juga tidak berbeda nyata. Berdasarkan hal tersebut, keragaan pertumbuhan benih populasi generasi pertama dan populasi kontrol dapat secara langsung dilihat dari ukuran panjang dan bobot akhirnya.

Keragaan pertumbuhan bobot dan panjang total ikan generasi pertama dari populasi terseleksi dan populasi kontrol (populasi dasar sintetis) selama 25 hari pada tahap pembenihan, 30 hari tahap pendederan dan 60 hari tahap pembesaran masing-masing disajikan pada Gambar 1 dan Gambar 2. Hasil tersebut menunjukkan bahwa keragaan pertumbuhan populasi generasi pertama relatif bagus, ditandai dengan telah tercapainya ukuran konsumsi (rata-rata $100 \mathrm{~g}$ ) hanya selama 40 hari masa pembesaran (umur 95 hari). Pada umumnya, ukuran konsumsi ikan lele di Indonesia mulai tercapai setelah dua bulan (60 hari) masa pembesaran sejak benih tebar berukuran $5-7 \mathrm{~cm}$ dan proses pemanenan secara total dilakukan setelah tiga bulan masa pembesaran.

Berdasarkan data keragaan pertumbuhan bobot (Gambar 1) tersebut, populasi generasi

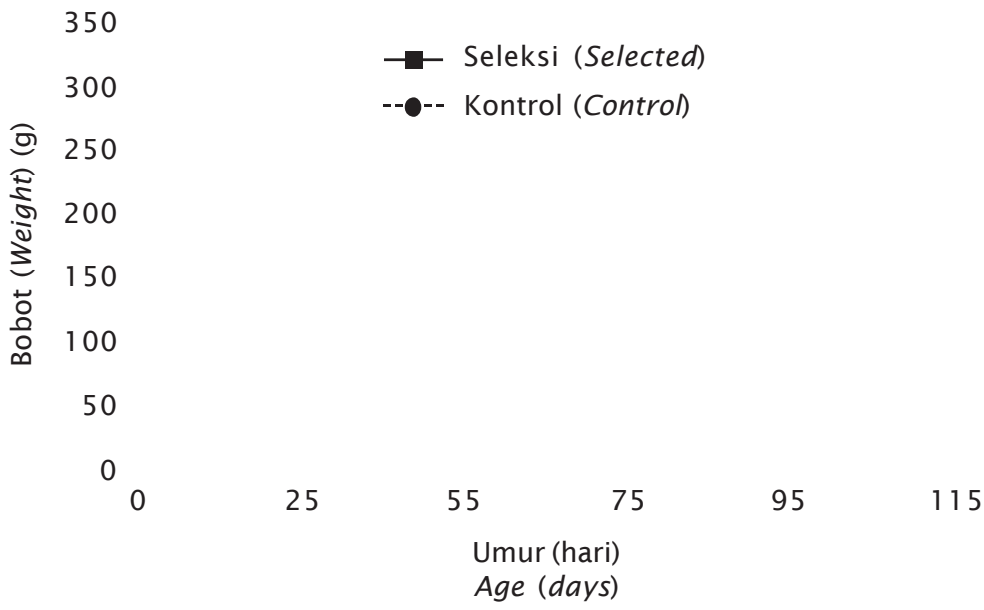

Gambar 1. Keragaan pertumbuhan bobot ikan lele Afrika hasil seleksi individu pada populasi generasi pertama dan populasi kontrol. Garis vertikal merupakan nilai simpangan baku

Figure 1. Growth perfomances based on weight increase of the first generation population and the control population. Vertical lines represent its each standard deviation 
pertama memiliki bobot akhir 200,72 $\pm 102,34$ g; sedangkan populasi kontrol berbobot $166,45 \pm 83,34 \mathrm{~g}$; sehingga terdapat respons seleksi sebesar 34,27 g (20,59\%). Keragaan pertumbuhan berdasarkan panjang total (Gambar 2) menunjukkan bahwa populasi generasi pertama memiliki ukuran panjang total akhir sebesar $29,16 \pm 4,35 \mathrm{~cm}$; sedangkan populasi kontrol berukuran $27,48 \pm 4,51 \mathrm{~cm}$; sehingga terdapat respons seleksi sebesar $1,68 \mathrm{~cm}(6,12 \%)$. Rasio konversi pakan selama dua bulan masa pembesaran sebesar 1,01 pada populasi generasi pertama dan 1,07 pada populasi kontrol.

Keberhasilan upaya peningkatan keragaan pertumbuhan beberapa spesies ikan budidaya melalui seleksi individu telah dilaporkan. Upaya peningkatan keragaan pertumbuhan ikan salmon Salmo trutta fario di Perancis melalui empat generasi seleksi individu yang teknik-tekniknya diperbaiki menghasilkan respons seleksi per generasi pada karakter bobot sebesar $21,5 \%$ atau sebesar $6,2 \%$ pada karakter panjang cagak (fork length) (Chevassus et al., 2004), relatif sama dengan hasil pada penelitian ini. Seleksi individu dalam upaya peningkatan pertumbuhan bobot ikan Ictalurus punctatus di Amerika Serikat selama selama tiga generasi menghasilkan respons seleksi kumulatif sebesar 29\% pa- da strain Kansas dan 21\% pada strain Marion (Rezk et al., 2003). Upaya peningkatan keragaan pertumbuhan (bobot) ikan Megalobrama amblycephala melalui seleksi individu di Cina menghasilkan respons seleksi per generasi selama lima generasi rata-rata sebesar 5,4\% (Li \& Cai, 2003). Demikian pula, upaya peningkatan keragaan pertumbuhan ikan tawes (Barbodes gonionotus) di Bangladesh melalui seleksi individu juga dilaporkan menghasilkan respons seleksi yang positif, yakni per generasi sebesar $7,2 \%$; dengan akumulasi selama tiga generasi sebesar 21,9\% (Hussain et al., 2002). Namun demikian, upaya peningkatan keragaan pertumbuhan melalui seleksi individu pada ikan karper (Cyprinus carpio) dan ikan nila (Oreochromis niloticus) yang pernah dilakukan sebelumnya dilaporkan tidak efektif karena besarnya pengaruh perbedaan kondisi lingkungan antar sistem budidaya pada spesies-spesies ikan tersebut dan rendahnya keragaman genetis pada populasi dasar karena sedikitnya jumlah ( $\mathrm{Ne}=$ effective breeding number) pasangan induk-induk pembentuknya, serta pengaruh maternal karena digunakannya teknik pemijahan secara massal (tidak terkontrol) (di-review oleh Lutz, 2001; Chevassus et al., 2004; Gjedrem \& Baranski, 2009). Induk-induk pembentuk populasi generasi pertama ikan lele tumbuh cepat yang dibentuk melalui seleksi individu

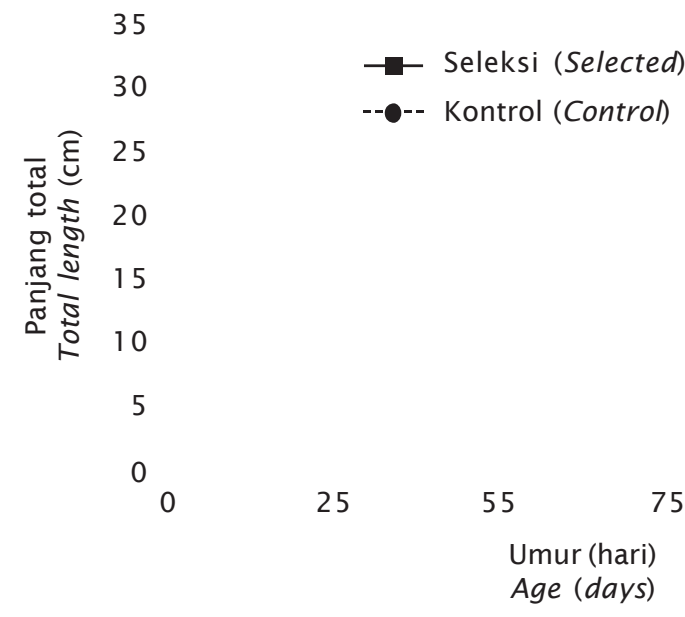

Gambar 2. Keragaan pertumbuhan panjang total ikan lele Afrika hasil seleksi individu pada populasi generasi pertama dan populasi kontrol. Garis vertikal merupakan nilai simpangan baku

Figure 2. Growth perfomances based on total length increase of the first generation population and the control population. Vertical line represent its each standard deviation 
pada penelitian ini berjumlah 100 ekor (50 pasang), sebagaimana yang disarankan oleh Chevassus et al. (2004). Demikian pula, untuk mengurangi pengaruh maternal, proses pemijahan keseluruhan induk pada penelitian ini dilakukan secara serentak pada hari yang sama, sebagaimana disarankan oleh Chevassus et al. (2004), melalui teknik pemijahan buatan.

\section{Populasi Kontrol dan Populasi Generasi Pertama Hasil Seleksi}

Populasi generasi pertama yang akan digunakan dalam pembentukan populasi generasi-generasi berikutnya dibentuk pada akhir masa pembesaran (pada saat pemanenan) melalui seleksi individu berdasarkan keragaan pertumbuhannya, sebagaimana disarankan oleh Brummet (2008) dan Nguyen \& Ponzoni (2008). Seleksi pada saat pemanenan dilakukan berdasarkan keunggulan karakter laju pertumbuhan, yakni hanya individuindividu dengan laju pertumbuhan tertinggi yang pada saat pemanenan dipilih untuk digunakan sebagai dasar pembentuk populasi generasi berikutnya. Keunggulan karakter laju pertumbuhan individu-individu yang terjadi pada saat pemanenan tersebut diharapkan akan diwariskan dan dapat ditingkatkan pada generasi-generasi berikutnya melalui program seleksi.
Sebaran ukuran individu-individu populasi generasi pertama pada saat pemanenan disajikan pada Gambar 3 dan 4. Pada saat pemanenan dilakukan seleksi individu dengan cara memilih 5\% individu-individu dari populasi yang berukuran terbesar, yakni yang berbobot lebih besar dari 416,40 g (panjang total lebih dari $37,8 \mathrm{~cm}$ ); sehingga terbentuk populasi generasi pertama terseleksi. Selain itu, pada saat pemanenan juga dipilih individu-individu yang berukuran rata-rata (bobot sekitar 200,72 g; panjang total sekitar 29,2 cm) sebanyak 100 ekor sebagai populasi kontrol. Populasi generasi pertama terseleksi akan digunakan sebagai pembentuk populasi generasi kedua, sedangkan populasi kontrol akan dipergunakan sebagai pembanding yang mewakili (representasi) keragaan populasi generasi pertama.

Berdasarkan data individu populasi generasi pertama terseleksi dan kontrol tersebut, nilai diferensial seleksi dapat dihitung, yakni sebesar 359,99 g (179,35\%) untuk bobot badan atau $12,3 \mathrm{~cm}(42,03 \%)$ untuk panjang total. Penerapan diferensial yang tinggi tanpa mengabaikan jumlah induk efektif $(\mathrm{Ne}) \mathrm{mi}-$ nimum tersebut diharapkan juga akan dapat menghasilkan respons seleksi yang positif pada program seleksi generasi kedua.

Heritabilitas nyata (realized heritability) karakter bobot pada saat pemanenan setelah

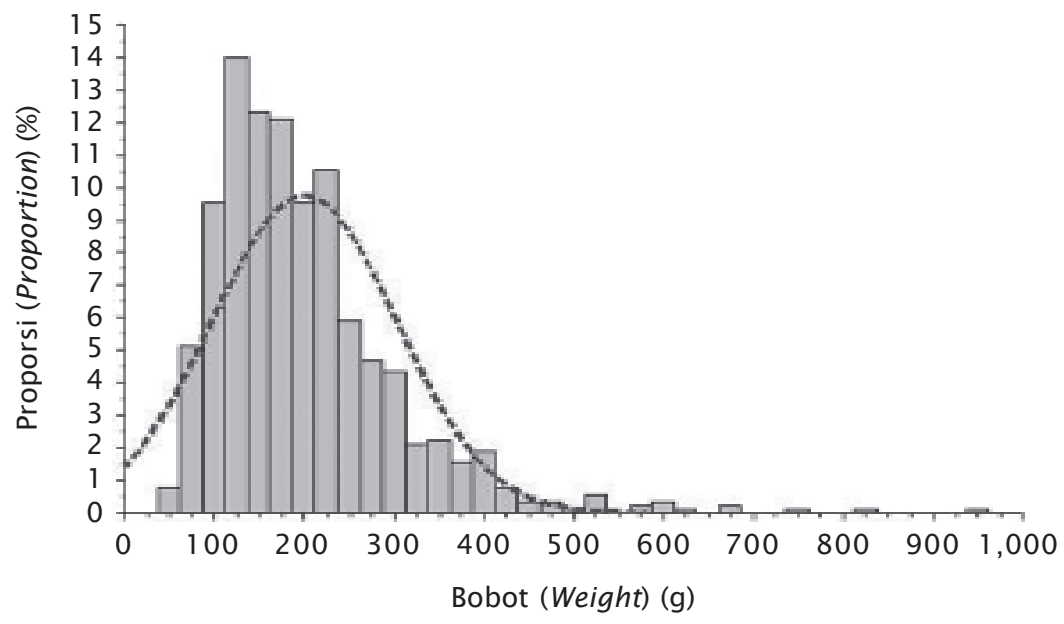

Gambar 3. Distribusi ukuran bobot ikan lele Afrika populasi generasi pertama pada saat pemanenan berdasarkan pengukuran sampel sebanyak $5 \%$ ( 1.000 ekor)

Figure 3. Weight size class distribution of the first generation population at harvest based on sampling of $5 \%$ population ( 1,000 fishes) 


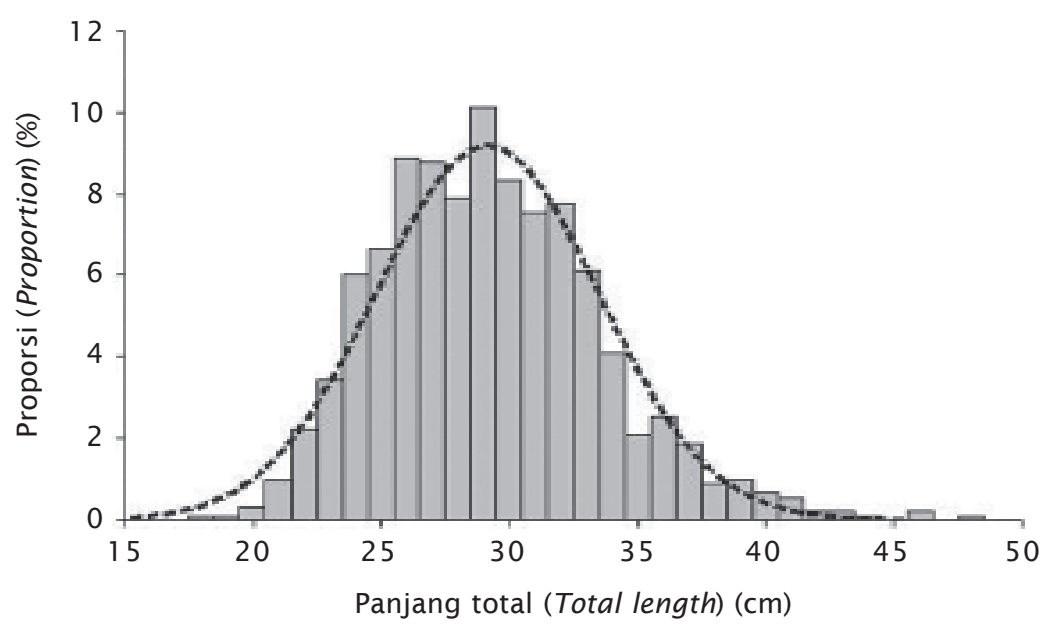

Gambar 4. Distribusi ukuran panjang total ikan lele Afrika populasi generasi pertama pada saat pemanenan berdasarkan pengukuran sampel sebanyak $5 \%$ ( 1.000 ekor)

Figure 4. Total length size class distribution of the first generation population at harvest based on sampling of 5\% population (1,000 fishes)

dua bulan dalam masa pembesaran (umur 115 hari) pada penelitian ini sebesar 0,11 . Hasil tersebut menunjukkan bahwa $11 \%$ keragaman bobot tersebut dipengaruhi oleh keragaman genetis aditif. Nilai tersebut menunjukkan heritabilitas yang rendah. Demikian pula, heritabilitas nyata pada karakter panjang totalnya juga rendah, yakni sebesar 0,13 . Menurut para ahli, nilai heritabilitas yang rendah mengindikasikan bahwa program seleksi individu tidak efektif untuk diterapkan, sehingga seleksi famili merupakan program seleksi yang direkomendasikan (Lutz, 2001; Beaumont \& Hoare, 2003; Kapuscinski \& Miller, 2007; Gjedrem \& Baranski, 2009; Beaumont et al., 2010). Namun demikian, nilai heritabilitas yang dimaksud tersebut merupakan nilai heritabilitas yang bersifat estimasi (estimated heritability), bukan nilai heritabilitas nyata. Heritabilitas hasil estimasi tersebut dihitung ketika program seleksi belum dilakukan dan heritabilitas tersebut dilaporkan bersifat bias (Lutz, 2001; Beaumont \& Hoare, 2003; Beaumont et al., 2010), serta tidak dapat diaplikasikan secara langsung pada program seleksi, karena umumnya diperoleh dalam kondisi eksperimental yang terkontrol dan berbeda dengan kondisi lingkungan pemeliharaan yang sebenarnya (Kapuscinski \& Miller, 2007). Sebaliknya, heritabilitas nyata diperoleh se- telah pelaksanaan kegiatan seleksi dan heritabilitas tersebut bersifat aktual (Beaumont \& Hoare, 2003; Beaumont et al., 2010).

Seleksi individu efektif diterapkan jika heritabilitas pada karakter tersebut tinggi dan jika ukuran populasinya besar sehingga diferensial seleksinya tinggi (Beaumont \& Hoare, 2003; Kapuscinski \& Miller, 2007; Beaumont et al., 2010). Meskipun heritabilitas karakter pertumbuhan pada pembentukan populasi generasi pertama ikan lele Afrika tumbuh cepat melalui seleksi individu ini tergolong rendah, tetapi diferensial seleksi yang diterapkan tinggi. Diferensial seleksi yang diterapkan pada seleksi individu dalam membentuk populasi dasar sintetis sebesar $331,47 \mathrm{~g}$ $(180,40 \%)$ atau $12,9 \mathrm{~cm}(46,88 \%)$ (Iswanto et al., 2012). Penerapan nilai diferensial seleksi yang tinggi pada seleksi individu karakter laju pertumbuhan ikan lele Afrika ini terbukti dapat menghasilkan respons seleksi selama satu generasi yang relatif tinggi (sebesar $20,59 \%$ berdasarkan ukuran bobot atau $6,12 \%$ berdasarkan panjang total). Satu generasi seleksi individu dalam upaya peningkatan keragaan pertumbuhan ikan nila di Filipina menghasilkan respons seleksi berdasarkan karakter panjang total sebesar $8 \%$, meskipun heritabilitasnya hanya sebesar 0,16 (Basaiao et al., 2005). 
Tabel 1. Nilai parameter kualitas air selama pemeliharaan

Table 1. Values of water quality parameters during the study

\begin{tabular}{lccc}
\hline \multicolumn{1}{c}{$\begin{array}{c}\text { Parameter } \\
\text { Parameters }\end{array}$} & $\begin{array}{c}\text { Pembenihan } \\
\text { Larval rearing }\end{array}$ & $\begin{array}{c}\text { Pendederan } \\
\text { Nursing }\end{array}$ & $\begin{array}{c}\text { Pembesaran } \\
\text { Grow out }\end{array}$ \\
\hline $\begin{array}{l}\text { Suhu (Temperature) }\left({ }^{\circ} \mathrm{C}\right) \\
\mathrm{pH}\end{array}$ & $29.0-32.4$ & $27.2-30.4$ & $27.0-30.6$ \\
Oksigen terlarut & $7.12-8.16$ & $7.17-7.46$ & $7.26-7.50$ \\
Dissolved oxygen (mg/L) & $3.32-5.59$ & $1.25-9.03$ & $1.91-2.38$ \\
Amoniak (Ammonia) (mg/L) & $0.0052-0.0346$ & $0.1855-0.3389$ & $1.6993-2.5120$ \\
Nitrit (Nitrite) (mg/L) & $0.0169-0.0841$ & $0.0101-0.0258$ & $0.0247-0.0421$ \\
\hline
\end{tabular}

Salah satu kesulitan dalam penerapan diferensial yang tinggi adalah berkaitan dengan jumlah individu terseleksi yang diperoleh. Diferensial seleksi yang tinggi tidak dapat diterapkan jika jumlah individu terseleksi yang dihasilkan hanya sedikit, karena hal tersebut dapat meningkatkan tingkat inbreeding melalui penggunaan (pemijahan) jumlah individu yang terbatas (Beaumont \& Hoare, 2003; Beaumont et al., 2010). Tetapi, hal tersebut tidak terjadi pada penelitian perakitan strain ikan lele Afrika tumbuh cepat melalui seleksi individu ini. Nilai diferensial seleksi yang tinggi pada penelitian ini menghasilkan jumlah individu terseleksi yang tinggi, yakni sekitar 400 ekor. Jumlah tersebut cukup memadai untuk proses pembentukan generasi berikutnya dengan tanpa mengabaikan jumlah induk efektif minimum yang disarankan, yakni menggunakan 50 pasang (100 ekor). Namun demikian, karakterisasi tingkat keragaman genetis untuk memastikan tingkat inbreeding populasi yang terbentuk melalui penggunaan teknologi marka molekuler perlu dilakukan secara rutin (Beaumont \& Hoare, 2003; Beaumont et al., 2010).

\section{Kualitas Air Media Pemeliharaan}

Kondisi kualitas air media pemeliharaan populasi generasi pertama dan populasi kontrol pada penelitian ini (Tabel 1) masih berada pada kisaran yang layak bagi kehidupan dan perkembangan ikan lele C. gariepinus. Secara umum, kisaran parameter kualitas air tersebut tidak melebihi rekomendasi batas nilai yang bersifat menghambat pertumbuhan ataupun bersifat letal pada ikan lele $C$. gariepinus, yakni suhu sekitar $28^{\circ} \mathrm{C}$, pH seki$\operatorname{tar} 7$, kadar amoniak < $10 \mathrm{mg} / \mathrm{L}$ dan kadar nitrit $<2 \mathrm{mg} / \mathrm{L}$ (Fleuren, 2008).

\section{KESIMPULAN DAN SARAN}

Program seleksi individu dalam rangka meningkatkan keragaan pertumbuhan ikan lele Afrika selama satu generasi pada penelitian ini menghasilkan respons seleksi yang positif, yakni sebesar $34,27 \mathrm{~g}(20,59 \%)$ atau sebesar 1,68 cm (6,12\%). Dengan demikian, populasi generasi pertama tersebut potensial untuk digunakan sebagai pembentuk generasi berikutnya dalam upaya perakitan strain unggul ikan lele tumbuh cepat melalui program seleksi individu. Selanjutnya, keragaman genetis populasi generasi pertama yang terbentuk (terseleksi) perlu diverifikasi melalui penggunaan teknologi marka molekuler.

\section{UCAPAN TERIMA KASIH}

Penulis menyampaikan terima kasih dan penghargaan yang sebesar-besarnya kepada seluruh teknisi komoditas penelitian ikan lele Balai Penelitian Pemuliaan Ikan atas bantuan teknisnya selama kegiatan pembenihan, pendederan, pembesaran, dan seleksi.

\section{DAFTAR ACUAN}

Basaiao, Z.U., Arago, A.L., \& Doyle, R.W. (2005). A farmer-oriented nile tilapia, Oreochromis niloticus L., breed improvement in the Philippines. Aquaculture Research, 36, 113 119.

Beaumont, A.R., Boudry, P., \& Hoare, K. (2010). Biotechnology and genetics in fisheries and aquaculture. Second Edition. Blackwell Science. Singapore, 202 pp.

Beaumont, A.R. \& Hoare, K. (2003). Biotechnology and genetics in fisheries and aquaculture. Blackwell Science. Oxford, 173 pp.

Brummet, R.E. (2008). Clarias catfish: biology, 
ecology, distribution and biodiversity. In: R.W. Ponzoni and N.H. Nguyen (eds.). Proceeding of a Workshop on the Development of a Genetic Improvement Program for African Catfish Clarias gariepinus. Accra, Ghana, 5-9 November 2007. WorldFish Center. Penang, Malaysia, p. 6472.

Chevassus, B., Quillet, E., Krieg, F., Hollebecq, M.G., Mambrini, M., Faure, A., Labbe, L., Hiseux, J.P., \& Vandeputte, M. (2004). Enhanced individual selection for selecting fast growing fish: the "PROSPER" method, with application in brown trout (Salmo trutta fario). Genetics of Selection and Evolution, 36, 643-661.

Fleuren, W. (2008). Reproductive and growout management of African catfish in the Netherlands. In Ponzoni, R.W. \& Nguyen, N.H. (Eds.), Proceeding of a Workshop on the Development of a Genetic Improvement Program for African Catfish Clarias gariepinus. Accra, Ghana, 5-9 November 2007. WorldFish Center. Penang. Malaysia, p. 73-78.

Gjedrem, T. (2005). Selection and breeding program in aquaculture. Springer. Netherlands, p. 251-277.

Gjedrem, T. \& Baranski, M. (2009). Selective breeding in aquaculture: An Introduction. Springer. Netherland, $221 \mathrm{pp}$.

Hardjamulia, A., Sukadi, M.F., Subagyo, \& Gustiano, R. (2001). Aquaculture genetics research in Indonesia. In Gupta, M.V. \& Acosta, B.O. (Eds.), Fish genetics research in member countries and institutions of the International Network on Genetics in Aquaculture. Proceeding of the Fifth Steering Committee of INGA. Kuala Lumpur, 3-5 March 1999. ICLARM - The WorldFish Center. Penang. Malaysia, p. 51-59.

Hussain, M.G., Islam, M.S., Hossain, M.A., Wahid, M.I., Kahinoor, A.H.M., Dey, M.M., \& Mazid, M.A. (2002). Stock improvement of silver barb (Barbodes gonionotus Bleeker) through several generations of genetic selection. Aquaculture, 204, 469-480.

Imron, Tahapari, E., \& Sunandar, D. (2011). Genetic variation of African catfish stocks in Indonesia as revealed by microsatellite DNA markers. Makalah dalam Seminar Hasil Penelitian Tahun 2010. Loka Riset Pemuliaan dan Teknologi Budidaya Perikanan Air Tawar. Sukamandi, $15 \mathrm{hlm}$.

Iswanto, B., Suprapto, R., Marnis, H., \& Imron.
(2012). Perakitan strain ikan lele Clarias gariepinus (Burchell, 1822) tumbuh cepat melalui seleksi individu: Pembentukan populasi dasar sintetis. Dalam Haryanti, Rachmansyah, Sugama, K., Parenrengi, A., Sudradjat, A., Imron, Sunarto, A., Sumiarsa, G.S., Azwar, Z.I., \& Kristanto, A.H. (Penyunting). Prosiding INDOAQUA - Forum Inovasi Teknologi Akuakultur 2012, hlm. 1.1971.210 .

Kapuscinski, A.R. \& Miller, L.M. (2007). Genetics guidelines for fisheries management. University of Minnesota Sea Grant Program. Minnesota, $116 \mathrm{pp}$.

Kementerian Kelautan dan Perikanan (KKP). (2010). Rencana strategis Kementerian Kelautan dan Perikanan 2010-2014. Kementerian Kelautan dan Perikanan. Jakarta, $84 \mathrm{hlm}$.

Li, S.F. \& Cai, W.Q. (2003). Genetic improvement of the herbivorous blunt snout bream (Megalobrama amblycephala). Naga, WorldFish Center Quarterly, 26(1), 20-23.

Lutz, C.G. (2001). Practical genetics for aquaculture. Fishing News Book. London, 252 pp.

Martins, C.I.M., Aanyu, M., Schrama, J.W., \& Verreth, J.A.J. (2005a). Size distribution in African catfish (Clarias gariepinus) affect feeding behaviour but not growth. Aquaculture, 250, 300-307.

Martins, C.I.M., Schrama, J.W., \& Verreth, J.A.J. (2005b). Inherent variation in growth effiency of African catfish Clarias gariepinus (Burchell, 1822) juveniles. Aquaculture Research, 36, 868-875.

Martins, C.I.M., Schrama, J.W., \& Verreth, J.A.J. (2005c). The consistency of individual differences in growth, feed efficiency and feeding behaviour in African catfish Clarias gariepinus (Burchell 1822) housed individually. Aquaculture Research, 36, 1509 1516.

Na-Nakorn, U. \& Brummet, R.E. (2009). Use and exchange of aquatic genetic resources for food and aquaculture: Clarias catfish. $R e$ views in Aquaculture 1, p. 214-223.

Nguyen, N.H. \& Ponzoni, R.W. (2008). Prospect for development of a genetic improvement program in African catfish (Clarias gariepinus). In Ponzoni, R.W. \& Nguyen, N.H. (Eds.), Proceeding of a Workshop on the Development of a Genetic Improvement Program for African Catfish Clarias gariepinus. Accra, Ghana, 5-9 November 
2007. WorldFish Center. Penang. Malaysia, p. 104-115.

PUSLENAS. (2010). Protokol Pemuliaan Ikan Lele dan Perbanyakan Induk Ikan Lele. Pusat Induk Lele Nasional (PUSLENAS). Sukabumi, $45 \mathrm{hlm}$.

Rezk, M.A. (2008). Genetic improvement of Clarias gariepinus at the WorldFish Center, Abassa, Egypt. In Ponzoni, R.W. \& Nguyen, N.H. (Eds.), Proceeding of a Workshop on the Development of a Genetic Improvement Program for African Catfish Clarias gariepinus. Accra, Ghana, 5-9
November 2007. WorldFish Center. Penang. Malaysia, p. 96-103.

Rezk, M.A., Smitherman, R.O., Williams, J.C., Nichols, A., Kucuktas, H., \& Dunham, R.A. (2003). Response to three generations of selection for increased body weight in channel catfish, Ictalurus punctatus, grown in earthen ponds. Aquaculture, 228, 69-79.

Volkcaert, F.A.M. \& Hellemans, B. (1999). Survival, growth and selection in a communally reared multifactorial cross of African catfish (Clarias gariepinus). Aquaculture, $171,49-64$. 